\title{
Trends in overweight and obesity in Portuguese conscripts from 1986 to 2000 in relation to place of residence and educational level
}

\author{
Cristina Padez*
}

Departamento de Antropologia, Departamento de Antropologia, Rua do Arco da Traição, Universidade de Coimbra, 3000-056 Coimbra, Portugal

Received 8 March 2005; received in revised form 7 April 2006; accepted 18 May 2006 Available online 8 August 2006

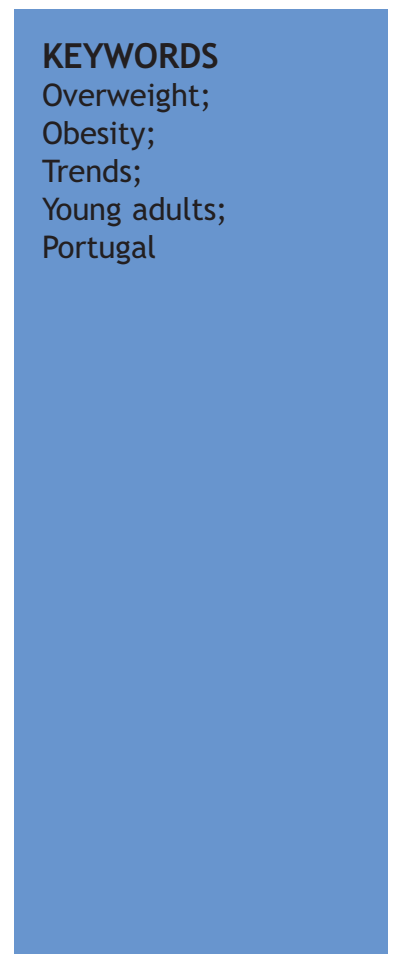

\begin{abstract}
Summary Objective: The aim of this study was to analyse changes in the prevalence of overweight and obesity between 1986 and 2000 in Portuguese conscripts, and to examine the role of place of residence and educational level. Study design: Cross-sectional study.

Methods: Data sets from the cross-sectional annual surveys of all 18-year-old Portuguese males born between 1966 and 1981 and examined between 1986 and 2000 (850 081 subjects) were used in this study. Height and weight were measured and body mass index was calculated. Data on educational level $(4,6,9,11$ and $12+$ years) and residence (urban, semi-urban and rural) were collected.

Results: The prevalence of overweight increased from $10.5 \%$ in 1986 to $21.3 \%$ in 2000 , and the prevalence of obesity increased from $0.9 \%$ to $4.2 \%$ in the same period $(P<0.001)$. After adjustment for year of examination, the odds ratio $(O R)$ for being overweight increased with educational level (reference 4-6 years: 1.19; 9 years: 1.30; 11 years: $1.47 ; 12$ + years: 2.41 ) and place of residence (reference urban-semiurban: 1.04 ; rural: 1.06$)$. The prevalence of obesity increased with educational level (reference $4-6$ years: $1.27 ; 9$ years: $1.79 ; 11$ years: $1.83 ; 12+$ years: 2.66 ) and decreased with place of residence, i.e. those who lived in rural areas had a lower risk of becoming obese (OR: 0.94).

Conclusions: Despite the low prevalence of obesity in young males in Portugal compared with other European countries, the sharp increase in recent years indicates that public health strategies are needed to prevent obesity.

(c) 2006 The Royal Institute of Public Health. Published by Elsevier Ltd. All rights reserved.
\end{abstract}

\footnotetext{
*Tel.: +351239 829051; fax: +351239823491.

E-mail address: cpadez@antrop.uc.pt.
} 


\section{Introduction}

An increased prevalence of overweight and obesity has been reported in many developed countries over the past decades. ${ }^{[1-8]}$ Moreover, there is growing evidence that excess weight is causally related to chronic diseases and all-cause mortality. ${ }^{[9]}$ Obesity is associated with an increased risk of hypertension, non-insulin-dependent diabetes mellitus, hyperlipidaemia and other chronic diseases. ${ }^{[10-12]}$

Several studies have shown that obesity in young adults has an adverse effect on morbidity and mortality. Many countries have reported an increase in the prevalence of obesity during the last few decades, and a serious increase in the associated health problems is anticipated. ${ }^{[13]}$ Obesity is a multifactorial problem and its development is due to multiple interactions between genes and the environment. ${ }^{[14]}$

Portugal has the highest stroke mortality rate in Western Europe, and cardiovascular diseases cause around $40 \%$ of deaths in Portugal. ${ }^{[15,16]}$ The only study of time trends in the prevalence of overweight and obesity used a selected sample of young males, from the District of Lisbon, at the time of military examination, and showed an increase in the percentage of males with body mass index (BMI) $>25 \mathrm{~kg} / \mathrm{m}^{2}$ from $8.1 \%$ in 1960 to $18.0 \%$ in $1990 .^{[17]}$ Another Portuguese study with a random sample of 1436 residents of Porto, aged 18-90 years, found that obese subjects showed a significantly higher prevalence of hypertension, hypertriglyceridaemia, diabetes and high-density-lipoprotein cholesterol concentration compared with subjects of normal weight. ${ }^{[18]}$

Obesity-related costs have been estimated to represent approximately $7 \%$ of the total healthcare expenditure in the USA, $1-5 \%$ in Europe and $3.5 \%$ in Portugal. $[13,19,20]$

This paper reports the first national study of overweight and obesity in 18-year-old Portuguese males. The aims were: (i) to analyse time trends in $\mathrm{BMI}$ distribution and the prevalence of overweight and obesity from 1986 to 2000; and (ii) to examine the influence of place of residence and educational level on the prevalence of overweight and obesity.

\section{Methods}

\section{Study population}

Data were obtained from medical examination records at the Portuguese district recruiting centres. Military service is compulsory in Portugal. All males born in a given year are examined by military physicians during their registration visit, which lasts for 3 days. The sample can thus be regarded as representing all regions of the country and all the social strata. All 18-year-old Portuguese males born between 1966 and 1981 and examined between 1986 and 2000 (850 081 subjects) were included. For 1991, data are absent due to technical problems, and for some other years, such as 1990 and 1993, the Portuguese Army only requested some males for the general examination. However, selection was made on a random basis throughout Portugal.

During the medical examination, height and weight are measured by a physician. For the present study, overweight and obesity were defined as a BMI of $25.0-29.9$ and $\geqslant 30.0 \mathrm{~kg} / \mathrm{m}^{2}$, respectively, using the cut-off points proposed by the World Health Organization. ${ }^{[21]}$

\section{Social data}

Residence details of the subjects were obtained and classified into three categories based on population size, following the classification of the Instituto Nacional de Estatística (INE): rural areas (population below 2000); semi-urban areas (population 2000-5000); and urban areas (population over 5000). Educational attainment was categorized into five levels according to the INE classification: primary (4 years); 6 years; secondary incomplete (9 years); secondary incomplete (11 years); and more than 12 years. Data on occupation were not collected.

\section{Statistics}

A simple П2 method, using a significance level of 0.05 , was used to determine the increase in overweight and obesity between 1986 and 2000 . Logistic regression analysis was performed to calculate odds ratios (OR) and 95\% confidence intervals $(\mathrm{Cl})$ for educational level and place of residence as risk factors for overweight and obesity. The results were adjusted for year of examination.

Statistical analysis was performed using SPSS Version 11.0 (SPSS Inc., Chicago, IL, USA).

\section{Results}

\section{Sociodemographic and health characteristics}

Table 1 summarizes the evolution of sociodemographic and health system characteristics in Portu- 


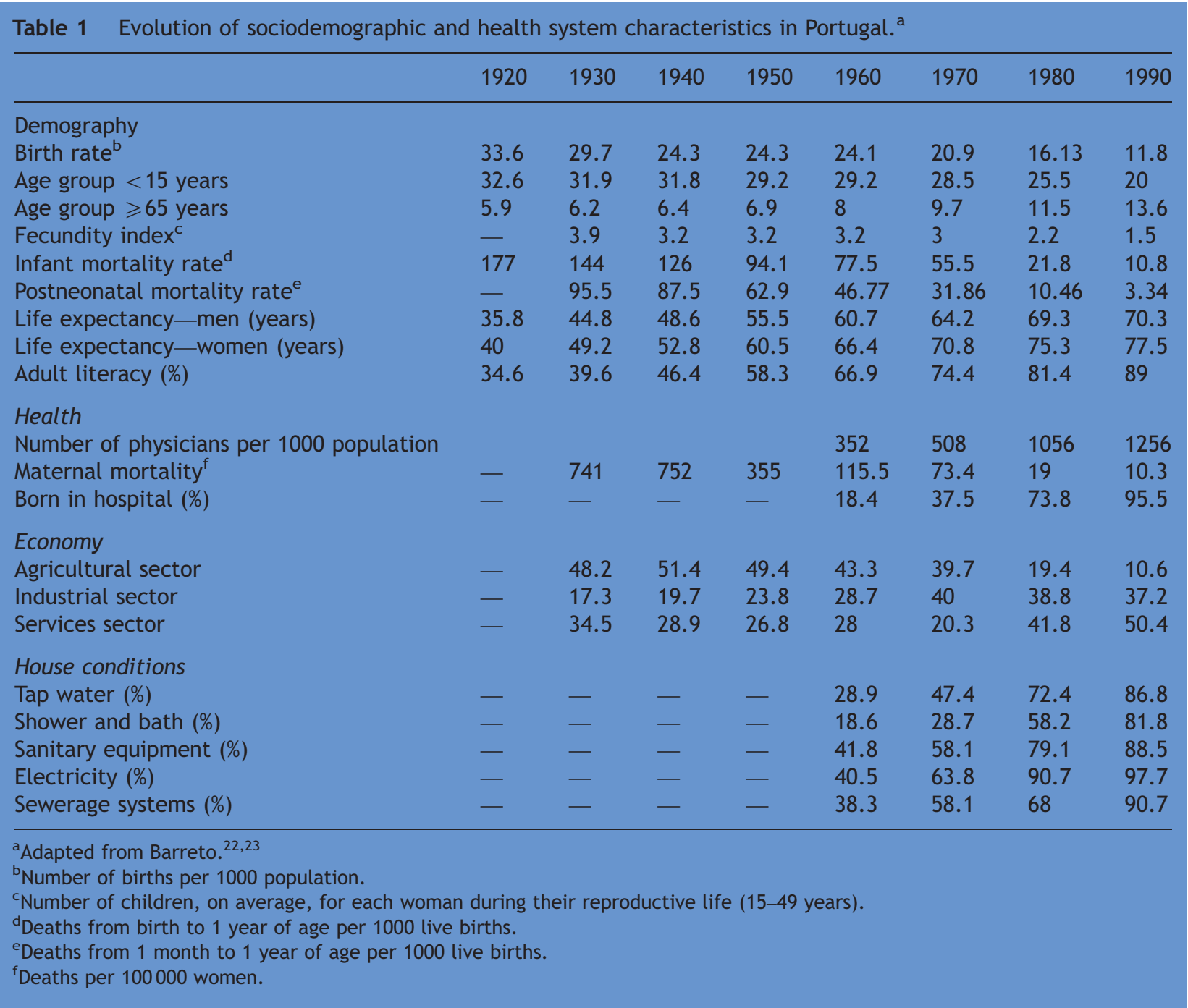

gal during the 20th Century. ${ }^{[22,23]}$ From 1920 to 1990 , birth rate, percentage of young people $(<15$ years), infant mortality rate and postneonatal mortality rate all showed a strong decrease. Simultaneously, the percentage of old people $(\geqslant 65$ years), life expectancy in both sexes, and adult literacy increased. The Portuguese health system also showed large changes. Between 1960 and 1990, the number of physicians per 1000 population and the percentage of newborns that were delivered in a hospital increased, and maternal mortality decreased. In the economic sector, the agricultural system decreased from $48.2 \%$ in 1930 to $10.6 \%$ in 1990 . On the other hand, the industrial and services sectors both increased in the same period, especially the industrial sector.

Taking in to account the changes in nutrition in the Portuguese population, Table 2 presents the total daily energy intake of some products. From the 1960 s to the $1990 \mathrm{~s}$, the consumption of some products increased substantially, such as milk (from
76 to $237 \mathrm{cal} /$ day), meat (from 78 to $328 \mathrm{cal} /$ day), fats (from 407 to $788 \mathrm{cal} /$ day), sugar (from 209 to $350 \mathrm{cal} /$ day) and eggs (from 14 to $30 \mathrm{cal} /$ day). The consumption of calories increased from 2671 to 3577 calories between 1960 and 1990.

\section{BMI distributions}

Figure 1 shows the BMI distributions in 1986 and 2000. Mean BMI values have increased over time, and the $\mathrm{BMI}$ distributions are skewed to the right in the last period of 2000.

\section{Trends in overweight and obesity}

The prevalence of overweight and obesity in 1986 and 2000 are shown in Figs. 2 and 3, respectively. The prevalence of overweight increased from 10.5\% to $21.3 \%$, and the prevalence of obesity increased from $0.9 \%$ to $4.2 \%\left(\chi^{2}=14079.5, P<0.001\right)$. 


\begin{tabular}{|c|c|c|c|c|c|c|c|}
\hline \multirow[b]{2}{*}{ Food } & \multicolumn{7}{|l|}{ Year } \\
\hline & 1963 & 1970 & 1980 & 1985 & 1990 & 1995 & 1997 \\
\hline Meat & 78 & 123 & 197 & 192 & 270 & 312 & 328 \\
\hline Milk & 76 & 117 & 140 & 172 & 213 & 227 & 237 \\
\hline Fats & 407 & 518 & 617 & 687 & 734 & 784 & 788 \\
\hline Sugar & 209 & 279 & 344 & 332 & 335 & 345 & 350 \\
\hline Eggs & 14 & 16 & 21 & 25 & 29 & 30 & 30 \\
\hline Calories & 2671 & 2940 & 2980 & 3127 & 3389 & 3544 & 3577 \\
\hline Calories $^{\mathrm{b}}$ & 2843 & 3098 & 3093 & - & 3601 & 3752 & 3773 \\
\hline Proteins (g) & - & - & 87.9 & 92.2 & 108.5 & 115.1 & 116.5 \\
\hline Fats (g) & - & - & 99.7 & 109.3 & 123.7 & 132.7 & 135.3 \\
\hline $\mathrm{HC}(\mathrm{g})$ & - & - & 432.9 & 443.7 & 463.5 & 476.6 & 477.9 \\
\hline
\end{tabular}

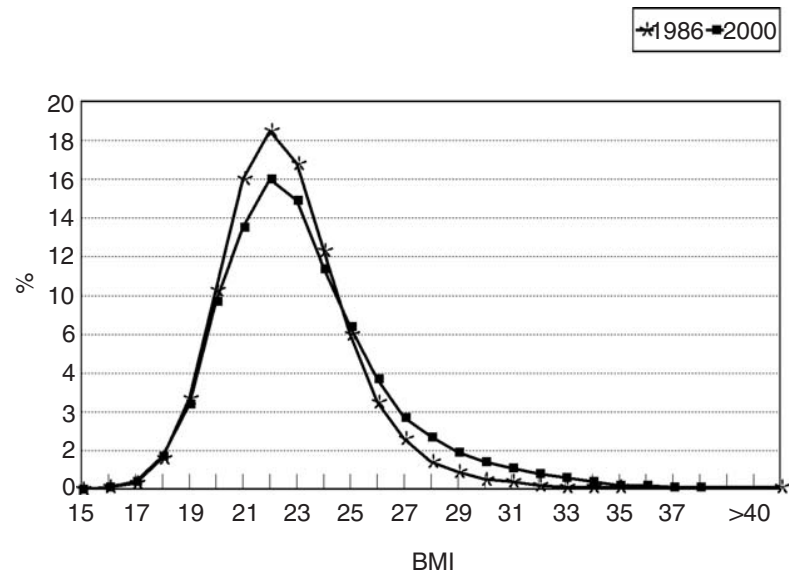

Figure 1 Distributions of body mass index for 18-yearold males observed in 1986 and 2000.

\section{Overweight}

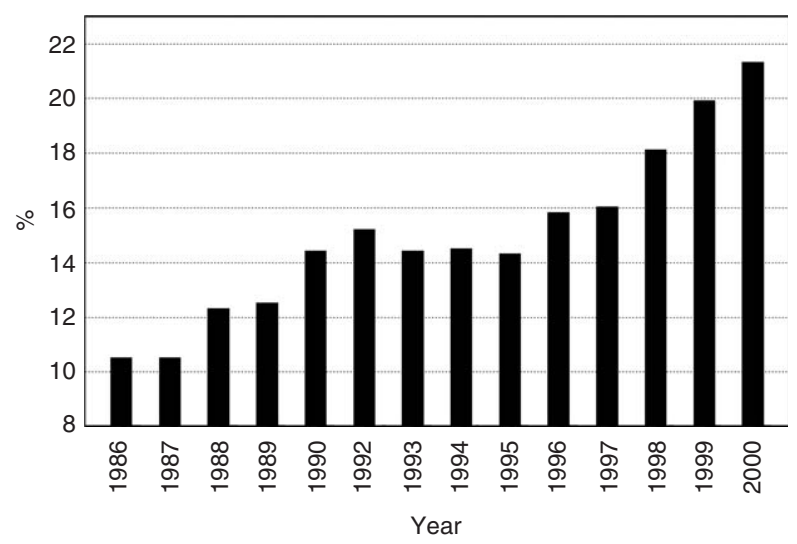

Figure 2 Prevalence of overweight (body mass index 25.0-29.9) by year of examination.

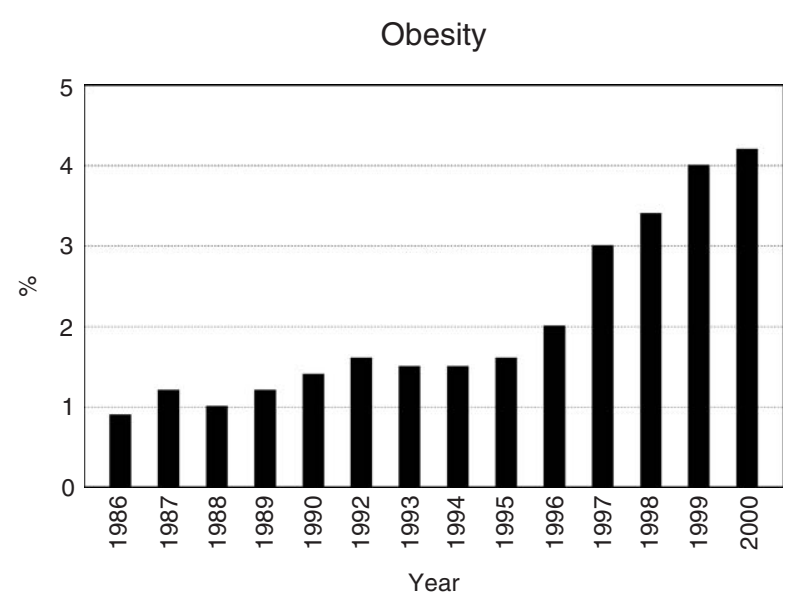

Figure 3 Prevalence of obesity (body mass index $\geqslant 30.0$ ) by year of examination.

\section{Educational level and place of residence}

Table 3 shows the ORs for overweight and obesity in relation to educational level and place of residence, both adjusted for year of examination. Males with more than 12 years of education showed a higher risk of being overweight $(\mathrm{OR}=2.41,95 \% \mathrm{Cl}$ 2.40-2.42) or obese $(\mathrm{OR}=2.66,95 \% \mathrm{Cl} 2.65-2.67)$ compared with males with a lower level of education.

Males who lived in rural areas were at greater risk of being overweight $(O R=1.06,95 \% \mathrm{Cl}$ 1.05-1.07) and at lower risk of being obese $(\mathrm{OR}=0.94,95 \% \mathrm{Cl}$ 0.93-0.95) compared with males who lived in urban and semi-urban areas. The present place of residence was used in this study, which is not an indicator of how long subjects 


\begin{tabular}{|c|c|c|c|c|c|c|}
\hline & \multicolumn{3}{|c|}{ Overweight } & \multicolumn{3}{|l|}{ Obesity } \\
\hline & $n$ & OR & $(95 \% \mathrm{Cl})$ & $n$ & OR & $(95 \% \mathrm{Cl})$ \\
\hline \multicolumn{7}{|c|}{ Educational level } \\
\hline 4 years & 14873 & 1 & & 133734 & 1 & \\
\hline 6 years & 291969 & $1.19^{*}$ & $(1.18-1.19)$ & 258471 & $1.27^{*}$ & $(1.26-1.27)$ \\
\hline 9 years & 316151 & $1.30^{*}$ & $(1.29-1.31)$ & 278418 & $1.79^{*}$ & $(1.78-1.8)$ \\
\hline 11 years & 92425 & $1.47^{*}$ & $(1.46-1.48)$ & 79921 & $1.83^{*}$ & $(1.82-1.84)$ \\
\hline $12+$ years & 150798 & $2.41^{*}$ & $(2.40-2.42)$ & 119885 & $2.66^{*}$ & $(2.65-2.67)$ \\
\hline \multicolumn{7}{|c|}{ Place of residence } \\
\hline Urban & 724564 & $1.0^{*}$ & & & 1 & \\
\hline Semi-urban & 202442 & $1.04^{*}$ & $(1.034-1.046)$ & & $0.97^{*}$ & $(0.96-0.974)$ \\
\hline Rural & 50633 & $1.06^{*}$ & $(1.051-1.068)$ & & $0.94^{*}$ & $(0.93-0.95)$ \\
\hline
\end{tabular}

have lived in the same residence. However, for both overweight and obesity, the difference between the place of residence and the place of birth were not statistically significant (data not shown).

\section{Discussion}

Trends in the prevalence of obesity in European countries are available for several countries including England, Sweden, Finland, Germany, Spain and The Netherlands. ${ }^{[24]}$ The prevalence of obesity has increased by approximately $10-40 \%$ in the majority of European countries over the past 15 years. The most dramatic increase has been reported in the UK, where the prevalence of obesity has doubled in the past 15 years.

The present findings are of national relevance because they give a unique picture (because this sample represents all regions of Portugal and all social strata) of the magnitude of the problem of obesity in young Portuguese males. The main findings of this nationwide population-based study were an increase in mean BMI over time, and that BMI distributions are skewed to the right. In consequence, there has been a fairly strong upward trend in the prevalence of overweight and obesity in Portugal between 1986 and 2000; overweight increased from $10.5 \%$ to $21.3 \%$ and obesity increased from $0.9 \%$ to $4.2 \%$.

It is difficult to compare these results with those from other European studies because most other studies have reported prevalence for all adult age groups. However, it is possible to determine the overweight and obesity values in studies that separated their samples according to age group. For 2000 , the present values are lower $(4.2 \%)$ than those observed in The Netherlands (4.4\%), ${ }^{[25]}$ Norway $(10 \%),{ }^{[26]}$ Denmark $(4.6 \%)^{[27]}$ and Finland (8.6\%). ${ }^{[28]}$ Only Sweden $(3.2 \%)^{[5]}$ and France $(2.0 \%)^{[29]}$ showed lower values than those found in 18-year-old Portuguese males. However, despite these low values, the prevalence of overweight and obesity in Portugal has increased notably between 1986 and 2000.

Contrary to other studies that found a higher prevalence of obesity in subjects with low levels of education, this study found an inverse association between obesity and educational level, with subjects with a low level of education presenting with lower values of overweight and obesity than those with a higher level of education. To give some examples, in Belgium, Stam-Moraga et al. ${ }^{[30]}$ found a highly significant inverse gradient between level of education and the prevalence of obesity, even after adjustment for age. The same trend was found in Sweden and Canada. ${ }^{[31-33]}$ In The Netherlands, Visscher et al. ${ }^{[34]}$ adjusted for age and town and found an inverse association between obesity and educational level; those with a primary school education had a prevalence of obesity of $15.4 \%$ and those with a university education had a prevalence of obesity of $4.7 \%$. The reverse relationship found in Portugal could be related to occupation. Those with a low level of education generally had an occupation that required more physical work than those with a higher level of education. Unfortunately, the questionnaire completed during the registration visit did not collect data related to occupation or socio-economic status.

The ultimate cause of obesity is an energy imbalance in which the relative excess in energy intake is translated into an accumulation of fat in the organism. However, obesity is considered to be the result of a large number of factors, including 
genetic background and several factors related to the environment. The current prevalence and trends in obesity seem to be the result of rapid changes in socio-economic living conditions that have occurred in Portugal since the 1970s. The Portuguese nutrition pattern changed a great deal between 1960 and 1997. Consumption of some products, such as milk, meat, eggs, sugar, proteins and fats, increased considerably. In Italy, Ullizi and Terrenato ${ }^{[35]}$ stressed the importance of these dietary components on secular trends in Italian conscripts born in 1874 and 1960. In Japan, Takahashi ${ }^{[36]}$ linked the secular trend in height to the consumption of milk, which has risen steeply since the Second World War, and concluded that milk consumption among the younger generation was one of the most important reasons for the acceleration of growth. Some of the changes in consumption of some products had a positive effect on the secular changes in height in the Portuguese population, ${ }^{[37]}$ but an increase in total energy from $2671 \mathrm{cal} /$ day in 1963 to 3577 in 1997 and an increase in fat intake from $407 \mathrm{cal} / \mathrm{day}$ to 788 in 1997 also occurred. ${ }^{[22,23]}$ It is likely that these changes also contributed to the increase in obesity, although a paradoxical effect can be shown if one looks at this relationship in different parts of the world. In the UK, the prevalence of obesity and overweight has increased in spite of a decrease in total energy intake accompanied by a relative increase in fat intake, ${ }^{[38]}$ whereas in the USA, the increased prevalence of obesity has been accompanied by an increase in energy intake and a decrease in fat consumption. ${ }^{[39]}$

In addition to energy intake, the amount of energy expended, particularly that component of energy which is most variable and susceptible to modification (i.e. physical activity), may explain the increased prevalence of obesity in the developed world. In Portugal, the industrial and services sectors have increased over the last century, with the greatest changes in the 1970s. At the same time, the agricultural sector almost disappeared. All these changes show that the amount of energy expenditure at work is now minimal because the industrial and services sectors do not require a great amount of physical energy. There is observational and experimental evidence that increased physical activity reduces, or at least a stabilizes, body weight. ${ }^{[40]}$ Diet and physical activity, along with many other factors related to the recent social and economic changes in Portugal, could explain the increased prevalence of obesity in young Portuguese males in the last decade, despite the positive trend in stature in the Portuguese conscripts, ${ }^{[37]}$ which represents a general improve- ment in living conditions. This problem was also observed in children; Portugal showed the secondhighest mean values in overweight/obesity (31.56\%) compared with other European countries. Portugal has followed the trend of other Mediterranean countries such as Spain (30\%), Greece (31\%) and Italy (36\%). ${ }^{41]}$

The increased prevalence of obesity reported in Western societies and the Portuguese values reported in this study represent a threat for public health, as obesity is related to several chronic morbidities and disabilities. ${ }^{[32]}$ Weight gain prevention programmes are urgently required to stop this burden of disease and disability.

\section{Acknowledgements}

The author thanks the Portuguese Army High Command (Estado Maior do Exército) for their kindness in providing all the raw data.

\section{References}

1. Bielicki T, Szklarska A, Welon Z, Malina RM. Variation in the body mass index among young adult Polish males between 1965 and 1995. Int J Obes 2000;24:658-62.

2. Fogelholm M, Mannisto S, Vartiainen E, Pietinen P. Determinants of energy balance and overweight in Finland 1982 and 1992. Int J Obes 1996;20:1097-104.

3. Guliford MC, Rona RJ, Chinn S. Trends in body mass index in young adults in England and Scotland from 1973 to 1988. J Epidemiol Com Health 1992;46:187-90.

4. Kuczmarski RJ, Flegal KM, Campbell SM, Johnson CL. Increasing prevalence of overweight among US adults. JAMA 1994;272:205-11.

5. Sundquist K, Qvist J, Johansson S-E, Sundquist J. Increasing trends of obesity in Sweden between 1996/97 and 2000/01. Int J Obes 2003; doi:1038/sj.ijo.0802553.

6. Prentice AM. Obesity - the inevitable penalty of civilization? Br Med Bull 1997;53:229-37.

7. Seidell JC, Verschuren WMM, Kromhout D. Prevalence and trends of obesity in the Netherlands 1987-1991. Int J Obes 1995;19:924-7.

8. Sorensen TIA, Price RA. Secular trends in body mass index among Danish young men. Int J Obes 1990;4:411-9.

9. Calle EE, Thun MJ, Petrelli JM, Rodriguez C, Heath CW. Body mass index and mortality in a prospective cohort of US adults. N Engl J Med 1999;341:1097-105.

10. Hartz AJ, Rupley Jr DC, Riedlinger WF, Rimn WF, Rimn AA. Relationship of obesity to diabetes: influence of obesity level and body fat distribution. Prev Med 1983;12:351-7.

11. Foster CJ, Weinsier RL, Birch R, Norris DJ, Bernstein RS, Wang J, et al. Obesity and serum lipids: an evaluation of the relative contribution of body fat and fat distribution to lipid levels. Int J Obes 11:151-61.

12. Bjorntorp P. The associations between obesity, adipose tissue distribution and diseases. Acta Med Scand 1988;723(Suppl):121-34. 
13. Seidell JC. The impact of obesity on health status: some implications for health care costs. Int J Obes 1995;19(Suppl 6):S13-6.

14. Maffeis C. Aetiology of overweight and obesity in children and adolescents. Eur J Pediatr 2000;159(Suppl 1):S35-44.

15. World Health Organization: Regional Office for Europe. Highlights on health in Portugal World Health Organization; 2003. Available from: http://www.euro.who.int/document/ e62041.pdf.

16. Instituto Nacional de Estatística. Resultados definitivos. As Causas de Morte em Portugal 2000. Instituto Nacional de Estatística; 2003. Available from: http://www.ine.pt/prodserv/destaque/d020124-3/d020124-3.pdf.

17. Castro JJ, Dias JA, Batista F, Costa JG, Galvão-Teles A, Camilo-Alves A. Secular trends of weight, height and obesity in cohorts of young Portuguese males in the district of Lisboa: 1960 to 1990. Eur J Epidemiol 1998;14:299-303.

18. Santos AC, Barros H. Prevalence and determinants of obesity in an urban sample of Portuguese adults. Public Health 2003;117:430-7.

19. Colditz GA. Economic costs of obesity and inactivity. Med Sci Sports Exerc 1999;31:S663-7.

20. Pereira J, Mateus C, Amaral MJ. Custos da Obesidade em Portugal. Documento de Trabalho 4/99. Associação Portuguesa de Economia da Saúde; 1999.

21. World Health Organization. Obesity: preventing and managing the global epidemic. Geneva: World Health Organization; 2000.

22. Barreto A. A Situação Social em Portugal, 1960-1995, vol I. Lisboa: Instituto Ciências Sociais, Universidade de Lisboa; 1996.

23. Barreto A. A Situação Social em Portugal, 1960-1999, vol II. Lisboa: Instituto Ciências Sociais, Universidade de Lisboa; 2000.

24. Seidell JC. Time trends in obesity: an epidemiological perspective. Horm Met Res 1997;29:155-8.

25. Visscher TLS, Kromhout D, Seidell JC. Long-term and recent time trends in the prevalence of obesity among Dutch men and women. Int J Obes 2002;26:1218-24.

26. Jacobsen BK, Njolstad I, Thune I, Wilsgaard T, Lochen ML, Schirmer $\mathrm{H}$. Increase in weight in all birth cohorts in a general population. The Tromso Study, 1974-1994. Arch Int Med 2001;161:466-72.

27. Sorensen HT, Sabroe S, Gillman M, Rothman KJ, Madsen KM, Fischer P, et al. Continued increase in prevalence of obesity in Danish young men. Int J Obes 1997;21:712-4.
28. Lahti-Koski M, Jousilahti P, Pietinen P. Secular trends in body mass index by birth cohort in eastern Finland from 1972 to 1997. Int J Obes 2001;25:727-34.

29. Maillard G, Charles MA, Thibult N, Forhan A, Sermet C, Basdevant A, et al. Trends in the prevalence of obesity in the French adult population between 1980 and 1991. Int J Obes 1999;23:389-94.

30. Stam-Moraga MC, Kolanowski J, Dramaiix M, De Backer G, Kornitzer MD. Sociodemographic and nutritional determinants of obesity in Belgium. Int J Obes 1999;23:1-9.

31. Rasmussen F, Johansson M, Hansen HO. Trends in overweight and obesity among 18-year-old males in Sweden between 1971 and 1995. Acta Paediatr 1999;88:431-7.

32. Molarius A. The contribution of lifestyle factors to socioeconomic differences in obesity in men and women-a population-based study in Sweden. Eur J Epidemiol 2003; 18:227-34.

33. Huot I, Paradis G, Ledoux M. Factors associated with overweight and obesity in Quebec adults. Int $J$ Obes 2004;28:766-74.

34. Visscher TLS, Seidell JC, Molarius A, van der Kuip D, Hofman A, Witteman JCM. A comparison of body mass index, waist-hip ratio and waist circumference as predictors of all-cause mortality among the elderly: the Rotterdam study. Int J Obes 2001;25:1730-5.

35. Ulizzi L, Terrenato L. A comparison between the secular trends of stature and some socio-economic factors in Italy. $J$ Hum Evolution 1982;11:715-20.

36. Takahashi E. Secular trend in milk consumption and growth in Japan. Hum Biol 1984;56:427-37.

37. Padez C. Secular trend in stature in the Portuguese population (1904-2000). Ann Hum Biol 2003;30:262-78.

38. Prentice AM, Jebb SA. Obesity in Britain: gluttony or sloth? BMJ 1995;311:437-9.

39. Centers for Disease Control and Prevention. Daily dietary fat and total food-energy intakes: Third National Health and Nutrition Examination Survey, Phase I, 1988-1991. MMWR Morb Mortal Wkly Rep 1994;43:116-25.

40. Wolf AM, Gortmaker SL, Cheung L, Gray HM, Herzog DB, Colditz GA. Activity, inactivity and obesity: racial, ethnic and age differences among schoolgirls. Am J Public Health 1993;83:1625-7.

41. Padez C, Fernandes T, Mourão I, Moreira P, Rosado V. Prevalence of overweight and obesity in 7-9-year-old Portuguese children: trends in body mass index from 1970-2002. Am J Hum Biol 2004;16:670-8.

Available online at www.sciencedirect.com

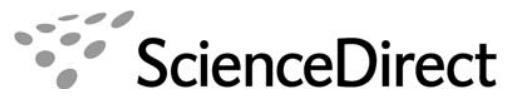

